\title{
Contribution of land use to rodent flea load distribution in the plague endemic area of Lushoto District, Tanzania
}

PROCHES HIERONIMO ${ }^{* 1}$, NGANGA I. KIHUPI', DIDAS N. KIMARO'1, HUBERT GULINCK ${ }^{2}$, LOTH S. MULUNGU ${ }^{3}$, BALTHAZAR M. MSANYA ${ }^{4}$, HERWIG LEIRS ${ }^{5}$ and JOZEF A. DECKERS ${ }^{2}$

'Department of Agricultural Engineering and Land Planning, Sokoine University of Agriculture, P.O. Box 3003, Morogoro, Tanzania

${ }^{2}$ Department of Earth and Environmental Sciences, University of Leuven, Celestijnenlaan 200E, Leuven, Belgium

${ }^{3}$ Pest Management Centre, Sokoine University of Agriculture, P. O. Box 3110, Morogoro, Tanzania

${ }^{4}$ Department of Soil Science, Sokoine University of Agriculture, P.O. Box 3008, Morogoro, Tanzania

${ }^{5}$ Evolutionary Ecology Group, Universiteit Antwerpen, Groenenborgerlaan 171, B-2020 Antwerpen, Belgium

\begin{abstract}
Fleas associated with different rodent species are considered as the major vectors of bubonic plague, which is still rampant in different parts of the world. The objective of this study was to investigate the contribution of land use to rodent flea load distribution at fine scale in the plague endemic area of north-eastern Tanzania. Data was collected in three case areas namely, Shume, Lukozi and Mwangoi, differing in plague incidence levels. Data collection was carried out during both wet and dry seasons of 2012. Analysis of Variance and Boosted Regression Tree (BRT) statistical methods were used to clarify the relationships between fleas and specific land use characteristics. There was a significant variation $(P \leq 0.05)$ of flea indices in different land use types. Fallow and natural forest had higher flea indices whereas plantation forest mono-crop and mixed annual crops had the lowest flea indices among the aggregated land use types. The influence of individual land use types on flea indices was variable with fallow having a positive effect and land tillage showing a negative effect. The results also demonstrated a seasonal effect, part of which can be attributed to different land use practices such as application of pesticides, or the presence of grass strips around fields. These findings suggest that land use factors have a major influence on rodent flea abundance which can be taken as a proxy for plague infection risk. The results further point to the need for a comprehensive package that includes land tillage and crop type considerations on one hand and the associated human activities on the other, in planning and implementation of plague control interventions.
\end{abstract}

Keywords: plague, land use, rodent, fleas, Tanzania

\section{Introduction}

Land use and human activities have been reported to be important determinants of vector borne disease transmission worldwide (Patz et al., 2004; Linard et al., 2007; Arinaminpathy et al., 2009). The transmission of vector-borne diseases including plague, have been related to peoples' exposure to vectors associated with land use patterns (Arinaminpathy et al., 2009; Vanwambeke et al., 2011).

Different studies have been conducted to explain the presence and the recurrence of plague in Lushoto District in north-eastern Tanzania. Some of these studies include those on persistence and continued outbreaks of plague (Kilonzo et al., 1997), patterns and spatial distribution of plague (Kamugisha et al., 2007), ecology and status of potential hosts and vectors (Laudisoit et al., 2007, 2009b; Laudisoit, 2009). Other studies focused on the influence of rainfall patterns on plague occurrence (Debien et al., 2010) and variation of flea abundance within and among habitat types (Laudisoit et al., 2009a). Hubeau (2010) found plague occurrence to be closely related to activity spaces for a number of land uses such as fetching water and collecting firewood.

Although a number of studies have generated some useful information on plague risk related to natural and land use factors, they fall short of elucidating the spatial variability of plague incidence in Lushoto District. Generally, human exposure to diseases has not been taken

\footnotetext{
*Correspondence: Proches Hieronimo; E-mail: phmusigula@gmail.com
} 
into account in studies of vector or host ecology (Linard et al., 2007). To complicate matters fleas have been reported to be an important vector of plague among wild rodents in scattered foci of the disease in equatorial Africa (Haeselbarth et al., 1966). Despite the important role played by rodent fleas in plague transmission (Makundi et al., 2008), knowledge on how land use practices affect the ecology of fleas living on and momentarily off-host is still lacking (Hubbart et al., 2011). This means, the association of fleas and specific land use types is poorly understood.

Detailed studies of landscape, land cover, and land use characteristics are important in the light of the coarse resolution of the available data of plague distribution and aggregated data of casualties at village or at most ward level (units of several square kilometres). A more detailed level of investigation is therefore necessary in order to link human related landscape characteristics to the presence of the potential hosts (rodents) and vectors (fleas) of plague, at comparable scale level. The main objective of this study was therefore, to investigate the contribution of land use to rodent flea load distribution at a fine scale in the plague endemic areas of Lushoto District in north-eastern, Tanzania. Specifically the study explored the land use attributes that can explain the abundance and distribution of rodent fleas at landscape scale.

\section{Materials and Methods}

\section{Study area}

The study was conducted in West Usambara Mountains, Lushoto District, Tanzania, in an area selected between Universal Transverse Mercator (UTM) coordinates $400000 \mathrm{~m} \mathrm{E}$ and $430000 \mathrm{~m}$ $\mathrm{E}$ and $9480000 \mathrm{~m} \mathrm{~N}$ and $9500000 \mathrm{~m} \mathrm{~N}$ Zone, 37M (Figure 1). The size of the area is 34,000 hectares and lies at an altitude ranging from 480 to 2,271 $\mathrm{m}$ above mean sea level. The area has a bimodal rainfall pattern with an annual total of $600-1,200 \mathrm{~mm}$. The study area is characterized by a mixed farming system with rainfed agriculture being the most important land use followed by irrigated agriculture, livestock keeping and off-farm activities such as petty cash and carpentry (Msita et al., 2010). Other land uses include natural forestry, plantation forests and utility woodlots (Kaoneka \& Solberg, 1994).

Study sites were selected to reflect a geographic gradient in the frequency of plague incidence, based on results from previous research in the area (Njunwa et al. 1989; Kilonzo et al., 1997; Davis et al., 2006; Kamugisha et al., 2007; Laudisoit et al., 2007, 2009a, b; Neerinckx et al., 2010). Four criteria were used for selection of sample areas: (a) The incidence of plague as recorded for the period from 1986-2004, which in former studies allowed to delineate the study area into zones of high incidence (plague incidence rate $=4.17-10.46$ cases $/ 1,000$ inhabitants), medium (1.91-4.17 cases/1,000 inhabitants) and low (0.02-1.91 cases/1,000 inhabitants); (b) Land use and human activity diversity; (c) Landform characteristics (plain, escarpment, plateau dissected at different levels and valleys); and (d) Climatic conditions. On the basis of these criteria, three sample areas (landscapes) were selected: (i) The Shume landscape (High plague incidence) - dissected upper part of the escarpment-edge of the plateau. The area is located in the cold dry zone (average temperature ranges from $15-19^{\circ} \mathrm{C}$ ), at an elevation ranging from 953$2040 \mathrm{~m}$ with an annual rainfall of 500-800 mm. The irregularly shaped $500 \mathrm{~m}$ deep escarpment has slopes up to 68 degrees and rock outcrops (Pfeiffer, 1990); (ii) The Lukozi landscape (Medium plague incidence) is characterised by strongly dissected plateau, with broad ridge crest/summits, characterised by deep soils. It is also situated in the cold dry zone with an average annual temperature ranging from $18-23^{\circ} \mathrm{C}$ and average annual rainfall of $1,000 \mathrm{~mm}$ at an elevation of $1750-$ 2205 m (Pfeiffer, 1990; Kaoneka \& Solberg, 1997); and (iii) The Mwangoi landscape (Low plague incidence) is characterised by a strongly dissected sunken part of the plateau. The climate of this area is hot and dry (average temperature $22^{\circ} \mathrm{C}$ ), with an annual rainfall of $500-800 \mathrm{~mm}$ (Pfeiffer, 1990). The altitude of the area ranges from 1,346-2,002 m. 


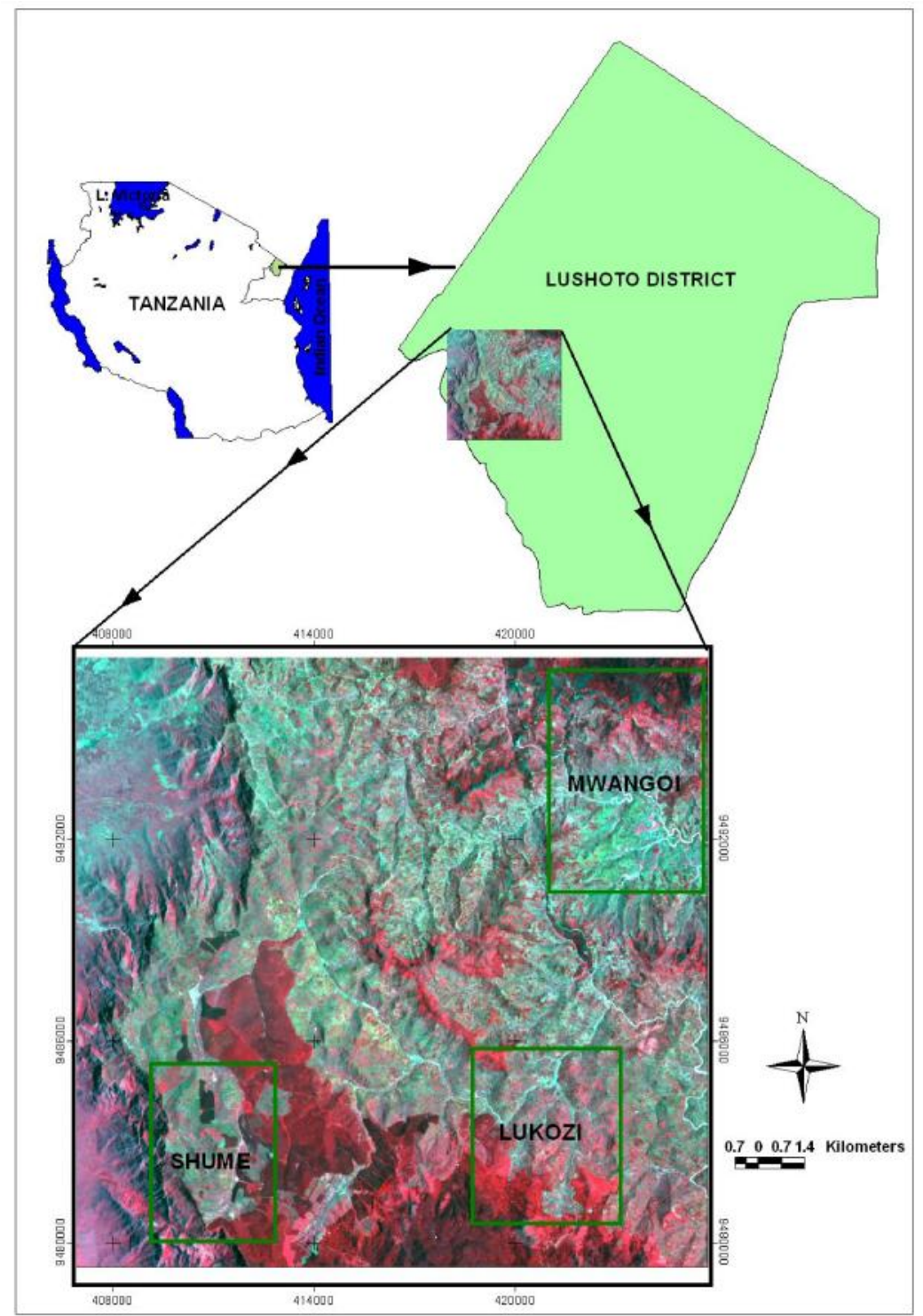

Figure 1: Location of study area: The Shume, Lukozi and Mwangoi landscapes in West Usambara Mountains, Tanzania

\section{Data collection procedure}

A total of 72 quadrats $100 \times 100 \mathrm{~m}$ were established. Twenty four quadrats were established per sample area (landscape). A stratified random sampling procedure based on broad land cover types and topography was used to locate the quadrats in each sample area. Decision on the number of observation sites considered representative sample size, time and human resources availability. At each observation site, data on land use, rodents and fleas from rodents were collected. Data collection was done in the wet season (April-June 2012) and the dry season (August-October 2012).

\section{Land use data}

At each of the observation sites various visible indicators of land use were georeferenced and mapped. Two major categories were defined: (a) Land management practices which were identified by their characteristic land cover patterns as seen in the field. Thus in this category five land use management types were mapped which include miraba, terraces, other hedge-like structures, tree stumps (dead and live) and fallow. Miraba is an indigenous land management 
practice with grass strips surrounding crop fields. "Other hedge-like structures" included crop fields demarcating grass/shrub strips, and hedges along footpaths/roads and around houses. Fallow was composed of such land cover type as bushed grassland, bushes, shrubs, unattended banana bushes, and inter-seasonal weedy/shrub fallow, or a mixture of these. (b) Crop types and other elements which were also identified by characteristic land cover patterns as seen in the field for example a field with a mixture of crops; each crop type was differentiated from other crops or physical features. In this group a total of 15 categories were mapped: maize, cassava, beans, potato, sugarcane, vegetables, settlement, Guatemala grass fields, tilled land, woodlot, rock outcrop, natural forest, plantation forest monocrop, plantation forest with farming going on or recently stopped and other land uses. The "vegetables" category had a mixture of such crops as: paprika, broccoli, carrot, tomato, cabbage, Chinese cabbage, zucchini, onion, beetroot, cauliflower and African eggplant. "Other land uses" category had a mixture of crops which were scant within quadrats. "Woodlots" had one or mixture of such land cover types as eucalyptus, grevillea, black wattle and pine woodlots. Each of the categories, natural forest, plantation forest monocrop and plantation forest with farming activities, was treated as single use in their respective observation sites. In the subsequent sections all mapped and quantified visible indicators of land use are referred to as "land use".

\section{Sampling and identification of rodent fleas}

Fleas were collected from small mammals captured mainly using Sherman LFA live traps (HB Sherman Traps, Tallahassee, USA) baited with peanut butter and maize flour. A total of 49 Sherman live traps spaced $10 \mathrm{~m}$ apart were set in a grid per trapping site (quadrat) and per trapping session. For the sites in natural forests, additionally two wire cages were used to capture somewhat bigger mammals like squirrels. Each trapping session lasted three nights. Each trap was inspected every morning and traps with captured animals were replaced by empty traps. Individual small mammals were identified to genus level or species level where possible (Eisen et al., 2012) and carefully combed for fleas. Fleas were stored in $70 \%$ ethanol in individual vials for each host specimen for subsequent identification. From collected small mammals and fleas, flea indices were later calculated per observation site. Flea index was calculated as the total number of fleas per total number of captured mammals (Laudisoit et al., 2009a). Flea index is a measure of flea abundance and was used as a response variable in the statistical analysis.

\section{Data analysis}

Two sets of data for Shume, Lukozi and Mwangoi were compiled and descriptive statistical analysis carried out.: The data set included: (a) Dry and wet season land use variables (b) Dry and wet season flea data (absolute number of fleas and flea index) and small mammal data (absolute number of animals). Prior to analysis of variance (ANOVA), data exploration to check for existence of outliers, normality and homogeneity was carried out (Zuur et al., 2010). Existence of outliers in the data was tested using box plots whereas normality was tested using the Kolmogorov-Smirnov test and homogeneity was tested using the Leven's test (Nienhuis \& Stout, 2009). Whenever normality was not fulfilled, data were $\log _{10}(x+3 / 8)$ transformed to achieve normal distributions (Axelsson et al., 2011; SAS Resource on the web, 2012). All the aforementioned statistical analyses were done in MS Excel and Minitab 14 software at the 95\% confidence level. A one way ANOVA of flea index among land use types was carried out on aggregated land uses data. For example wherever the observation site was dominated by both annual and perennial crops, the aggregated land use for that particular observation site was classified as 'Mixed annual perennial crops' and wherever the observation site was composed of natural forest only the aggregated land use type became 'Natural forest'. A total of seven groups of aggregated land uses (Plantation forest with farming, Natural forest, Fallow, Mixed annual crops, Mixed annual perennial crops, Plantation forest monocrop, Woodlot) were classified. Flea 
index was treated as a dependent variable and aggregated land use was treated as an independent variable.

Boosted Regression Trees (BRT) modelling technique in R software ( $\mathrm{R}$ Development Core Team, 2006) was used to establish the relationships between flea index and individual land use types. Models were fitted using the gbm.step function and a Gaussian response type, with most effective settings for learning rate (0.01-0.000001) and bag fraction (0.5-0.75) (Elith et al., 2008). Tree complexity was set to 3, according to recommendations by Elith et al. (2008) for small datasets. BRT-models were developed and validated using 10-fold cross validation (cv), with the benefit of still using the full dataset to fit the final model (Elith et al., 2008). The measure of model performance was cross validation deviance and standard error (Elith et al., 2008; Williams et al., 2010). The combination of learning rate and bag fraction settings with the lowest cv deviance and standard error was the one selected to produce the final BRT model (Williams et al., 2010). Partial dependency plots were used for interpretation and to quantify the relationship between each predictor variable and the flea index. Also during data exploration all predictor variables were tested for ecologically acceptable level of collinearity (i.e. individual variance inflation factor (VIF) of less than five) between predictor variables (Zuur et al., 2010; Aertsen et al., 2012). In construction of BRT models, flea indices were used as response variable and individual land uses were used as predictor variables. The unit of measurement for miraba, other hedge-like structures and terraces was length $(\mathrm{m})$ whereas tree stumps were counted (number). The rest of individual land use variables were measured as proportions of coverage (\%) of each land use within the sampled $100 \times 100 m$ quadrat.

\section{Results}

\section{Abundance and diversity of fleas in the landscapes}

The total absolute number of fleas and corresponding small mammals collected in both seasons are presented in Table 1. Most fleas were collected during the dry season (64.6\%). Similarly, more small mammals from which fleas were combed were collected during the dry season (52.6\%).

Table 1: Total number and percentage (\%) of fleas and small mammals collected

\begin{tabular}{lllll}
\hline Landscape & Fleas & \multicolumn{3}{c}{ Small mammals } \\
\cline { 2 - 4 } & Dry season & Wet season & Dry season & Wet season \\
\hline Shume & $358(53 \%)$ & $179(48 \%)$ & $265(46 \%)$ & $234(45 \%)$ \\
Lukozi & $180(27 \%)$ & $124(34 \%)$ & $232(40 \%)$ & $193(37 \%)$ \\
Mwangoi & $137(20 \%)$ & $67(18 \%)$ & $79(14 \%)$ & $93(18 \%)$ \\
Total & $675(64.6 \%)$ & $370(35.4 \%)$ & $576(52.6 \%)$ & $520(47.4 \%)$ \\
\hline
\end{tabular}

There was significant variation of flea index means $(p \leq 0.05)$ among aggregated land use types during the dry season but not in the wet season. During the dry season, the highest flea indices were observed in the fallow, natural forest, and woodlot land use types (Table 2). On the other hand, during the wet season, the highest flea index was observed in the fallow land use type but with a slightly lower value.

Table 2: Effect of aggregated land use on flea index

\begin{tabular}{lll}
\hline Season & Land use & Mean flea index \\
\hline Dry season & Fallow & 1.50 \\
& Natural forest & 1.24 \\
& Woodlot & 1.23 \\
& Plantation forest with farming & 0.9 \\
& Plantation forest monocrop & 0.24 \\
& Mixed annual crop & 0.25 \\
& Mixed annual perennial crop & 0.34 \\
\hline
\end{tabular}




\begin{tabular}{lll}
\hline Wet season & Fallow & 1.27 \\
Natural forest & 0.81 \\
Plantation forest with farming & 0.68 \\
Mixed annual crops & 0.35 \\
Mixed annual perennial crops & 0.35 \\
Plantation forest monocrop & 0.21 \\
Woodlot & 0.14 \\
\hline
\end{tabular}

Table 3 shows the diversity of collected fleas for the dry season. A total of 675 rodent fleas belonging to 14 identified species were collected during this season. Shume and Lukozi had more species diversity as well as absolute numbers of fleas than Mwangoi. The two species namely Xenopsylla brasiliensis and Dinopsyllus lypusus, which account for $35 \%$ of the total collection, were dominant in all three landscapes and are reported to be good plague vectors in the study area.

Table 3: Diversity of collected dry season rodent fleas species and their proportions for each of the three studied landscapes

\begin{tabular}{llll}
\hline Landscape & Shume & Lukozi & Mwangoi \\
\hline Rodent flea species & Count/Proportion & Counts/Proportion & Counts/Proportion \\
\hline Xenopsylla brasiliensis & $64(17.9 \%)$ & $15(8.3 \%)$ & $66(48.2 \%)$ \\
Xenopsylla cheopis & $1(0.3 \%)$ & $0(0.0 \%)$ & $1(0.7 \%)$ \\
Ctenophthalmus calceatus cabirus & $26(7.3 \%)$ & $15(8.3 \%)$ & $6(4.4 \%)$ \\
Nosopsyllus incisus & $63(17.6 \%)$ & $23(12.8 \%)$ & $4(2.9 \%)$ \\
Dinopsyllus lypusus & $58(16.2 \%)$ & $16(8.9 \%)$ & $18(13.1 \%)$ \\
Dinopsyllus grypurus & $8(2.2 \%)$ & $28(15.6 \%)$ & $27(19.7 \%)$ \\
Leptopsylla aethiopica aethiopica & $53(14.8 \%)$ & $16(8.9 \%)$ & $14(10.2 \%)$ \\
Ctenophthalmus leptodactylus & $0(0.0 \%)$ & $17(9.4 \%)$ & $0(0.0 \%)$ \\
Ctenophthalmus eximius & $73(20.4 \%)$ & $12(6.7 \%)$ & $0(0.0 \%)$ \\
Ctenophthalmus sp. & $8(2.2 \%)$ & $9(5.0 \%)$ & $0(0.0 \%)$ \\
Xenopsylla crinita & $0(0.0 \%)$ & $28(15.6 \%)$ & $0(0.0 \%)$ \\
Dinopsyllus sp. & $4(1.1 \%)$ & $0(0.0 \%)$ & $0(0.0 \%)$ \\
Lybiastus duratus & $0(0.0 \%)$ & $1(0.6 \%)$ & $0(0.0 \%)$ \\
Ctenophthalmus sp. & $0(0.0 \%)$ & $0(0.0 \%)$ & $1(0.7 \%)$ \\
\hline Total & 358 & 180 & 137 \\
\hline
\end{tabular}

\section{Influence of individual land use on flea index as demonstrated by BRT model}

Six land use variables (predictor variables) were identified by the BRT model to have influence (to be important) on the observed spatial pattern of flea index in the dry season (Figure 2). All six predictor variables had the ecologically acceptable level of individual variance inflation factor $(\mathrm{VIF}<5)$. Fallow was the most important predictor with contribution of more than a third of the total influence (39.5\%) and a strong positive effect. The presence of fallow between 0 and $20 \%$ appeared to be a precursor of increased rodent flea population (flea index). The second most important predictor was tillage with contribution of almost a third of the total influence $(32 \%)$ and a strong negative effect. The presence of at least $40 \%$ of tilled land appeared to trigger off reduction in rodent flea population. Other individual land use variables had lesser influence on flea index with "other hedge-like structures" ( $16.7 \%$ contribution) and miraba (6.5\% contribution) having a positive effect. 

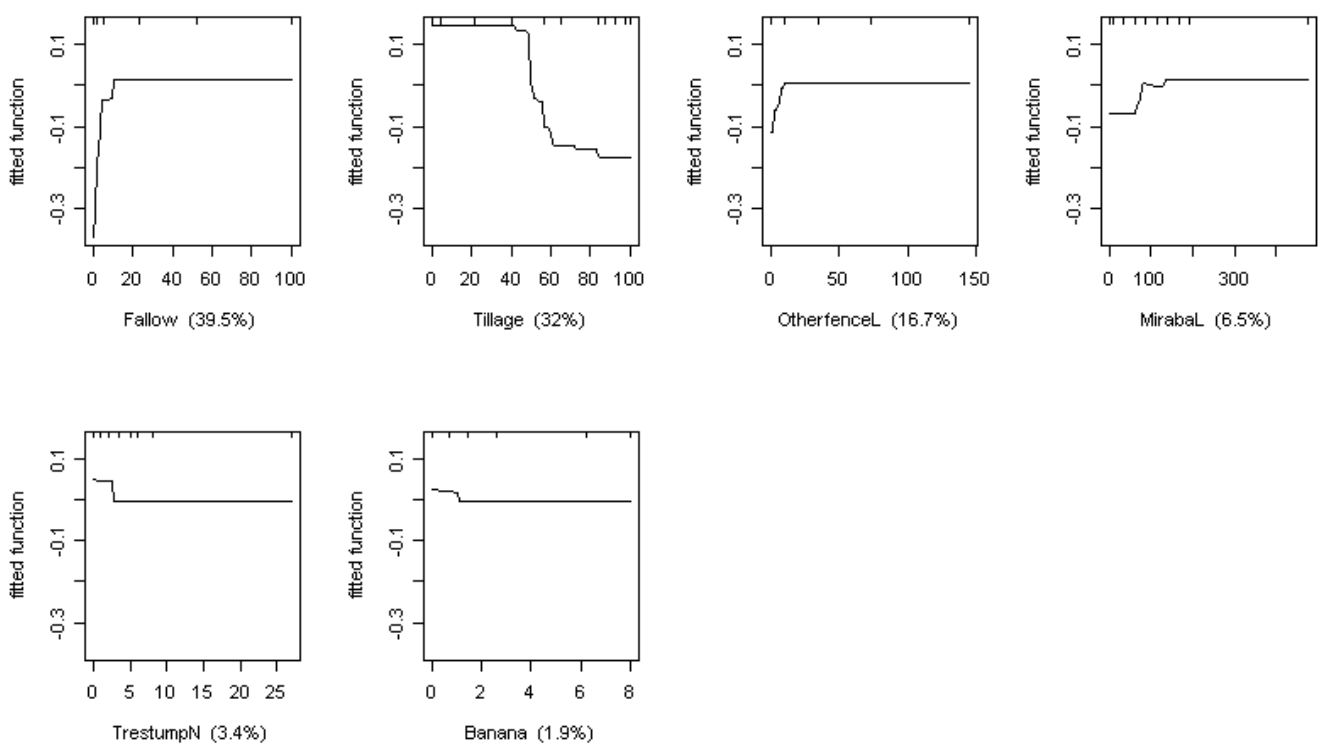

Key: TrestumpN= Tree stump, MirabaL=Miraba, OtherfenceL= Other hedge-like structures

Figure 2: Partial dependence plots showing the effect of individual land use on spatial pattern of flea index during dry season. The relative contribution of each predictor is reported between brackets; Cross Validation deviance $=0.637$, Standard Error $=0.354$, number of trees $=2,500$
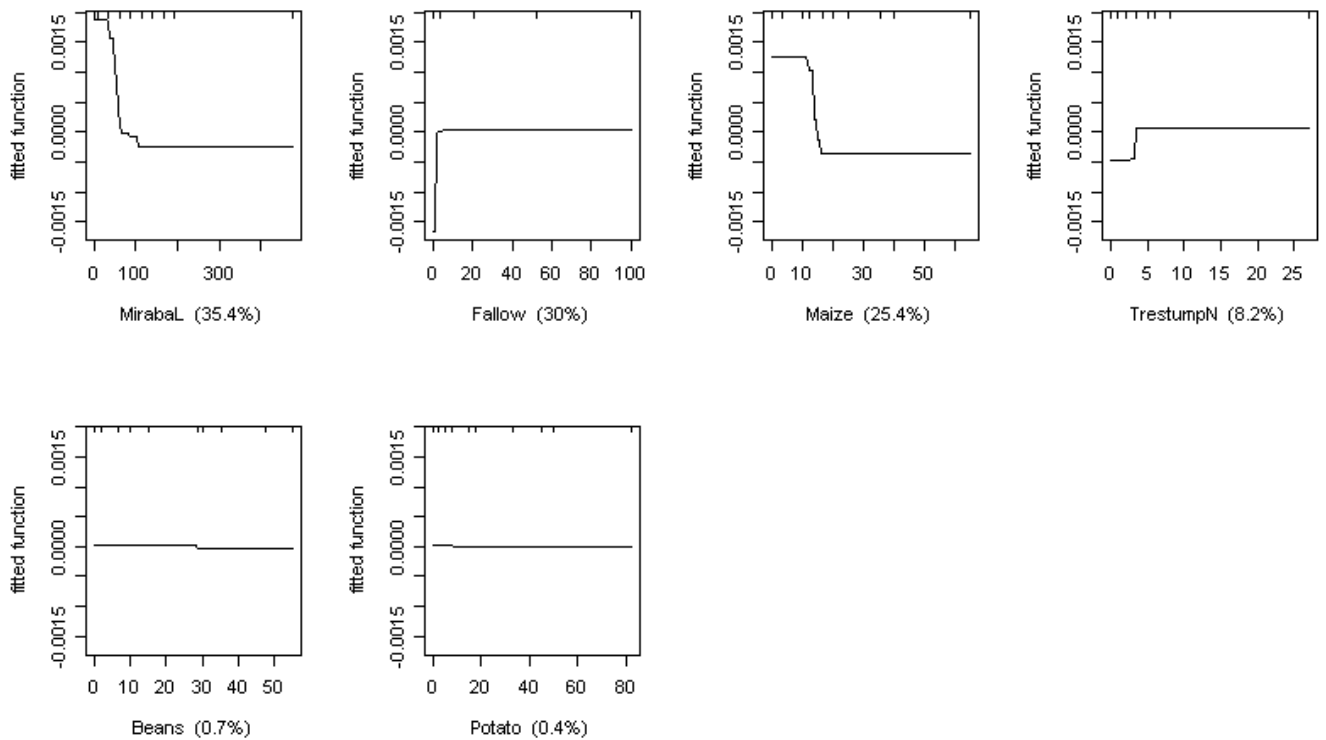

Key: TrestumpN= Tree stump, MirabaL=Miraba ,

Figure 3: Partial dependence plots showing the effect of land use on spatial pattern of flea index during wet season. The relative contribution of each predictor is reported between brackets; Cross Validation Deviance $=0.471$, Standard Error $=0.096$, Number of trees $=1000$

Six land use variables (predictor variables) were identified by the BRT model to have influence on the observed spatial pattern of flea index in the wet season (Figure 3). All six predictor variables had the ecologically acceptable level of individual variance inflation factor $(\mathrm{VIF}<5)$. Miraba was the most important predictor with contribution of almost a third of the total influence (35.5\%) 
and a strong negative effect. The presence of at least $50 \mathrm{~m}$ length of miraba was enough to trigger off a decrease in flea index. Fallow was the second most important predictor with contribution of close to a third of the total influence (30\%) and had immediate strong positive effect similar to the dry season. Like miraba, maize also had a strong negative effect contributing a quarter of the total influence. Other individual land use variables had lesser influence on rodent flea abundance.

\section{Discussion}

The observed variations of flea index among land use types could be attributed to the impact of land use practices on flea habitat structure (Laudisoit et al., 2009a; Hubbart et al., 2011). According to Hubbart et al. (2011), the microclimate affecting rodent flea abundance varies among land use types. For example in the current study, fallow land use type generated the highest mean flea index during both dry and wet seasons. This might be attributed to fallow structure providing conducive microclimate for fleas (Laudisoit et al., 2009a) on one hand and supply of both food and shelter for rodents on the other (Laudisoit et al., 2009b; Mulungu et al., 2011). Fallow fields have also been associated with plague cases in Uganda (Eisen et al., 2010; MacMillan et al., 2011). Since previous studies showed that flea index could be used as a proxy for plague infection risk in many areas including East Africa (Laudisoit et al., 2007; Pham et al., 2009; Zimba et al., 2011), findings from the current study further lend credence to the hypothesis that plague infection risk could be associated with fallow in the study area. On the other hand, the negative effect of land tillage (which takes place in the dry season) on flea index would seem to counteract the dry season build-up of rodent fleas in the area. This is because tillage of land which destroys surface and subsurface microclimate (Hubbart et al., 2011) could be detrimental to flea survival. In a study by Massawe et al. (2006) it was found that land preparation negatively affects the spatial distribution of rodents probably due to reduced cover (habitat) and food. The destruction of burrows may also lead to burying momentarily off host fleas hence reducing the load of fleas on rodents visiting or temporarily living in those burrows. This observation is of practical significance with regard to the need of clearing surroundings of homesteads and avoiding long fallow cycles.

The positive, albeit moderate influence of miraba and other hedge-like structures on flea index could be attributed to the fact that such land use types are associated with many rodent burrows (Kamugisha et al., 2007; Msita et al., 2011), and live rodent burrows are also likely to harbour adult 'free fleas' populations which momentarily stay in the burrows (Eisen et al., 2012). Since these land use types provide suitable habitats for rodents, there is a high possibility of rodents contacting higher number of fleas inside burrows (Hubbart et al., 2011). The study by Eisen et al. (2012) reported that off host adult populations of some flea species are able to survive while infected for relatively long periods in burrows or nests, thus contributing to the persistence of plague. The study conducted in the area by Kamugisha et al. (2007), showed that miraba with Guatemala grass which is usually grown on the steep slopes to prevent soil erosion and provision of pasture for zero grazed cattle, is likely to provide good shelter, breeding site and source of food for rodent populations. Such miraba planted with Guatemala and elephant grasses are frequently visited by humans during the dry season especially during fodder collection. Therefore, miraba are likely to be another potential plague infection risk land management practice that may need attention during epidemic periods.

The tree stumps appear to have variable influence on the spatial pattern of flea index, giving a positive effect during the wet season but a negative one during the dry season. Observations from the present study seem to suggest that tree stumps are an alternative choice for rodent nests especially in field areas where there are no miraba or terraces. On the other hand, the negative correlation depicted by miraba and maize land use types on flea index during the wet season could be a result of the effect of intensive use of fertilizers and pesticides leading 
to decreased populations of fleas (Hubbart et al., 2011). This situation may have a cleansing effect on the rodents which despite their numbers due to favourable conditions in terms of shelter (Msita et al., 2011) and food (Mulungu et al., 2011) are devoid of fleas, hence lowering the flea index. These findings highlight on the need for further research on the role of fertilizer and pesticides in plague control during the wet season. In a previous study in the area, Makundi et al. (2005) recommended an approach for plague control which is to intensify the control of fleas with insecticides outdoors during peak plague outbreak season. Another reason for the negative influence of miraba and maize may be due to weather and microclimate change because temperature and relative humidity impact flea survival (Gage et al., 2008; Ben Ari et al., 2011; Eisen et al., 2012). High rainfall may also cause flooding of burrows located in maize fields and hence resulting in death of fleas. Furthermore, the fact that all rodent fleas collected in the dry season are capable of transmitting Yersinia pestis with various vectors potential, this could have potentially important implications for the plague activity in relation to land use types in space and time (Eisen et al., 2006; Laudisoit, 2009).

Findings from this study seem to suggest that land use types have major influence on rodent fleas' abundance. The fact that a significant number of rodent fleas collected in the dry season from the study area are capable of transmitting $Y$. pestis, lends credence to the generally held view that flea index could be used as a proxy for plague infection risk in the area. The negative effect of some land use types on flea index especially during the wet season suspected to result from intensive use of farm inputs including pesticides supports the proposed plague control measures by Makundi et al. (2005). This also highlights the need for further research on the role of farm inputs such as fertilizers and pesticides in plague control. Furthermore, other land use types which impact negatively on flea index such as land tillage done in the dry season, point to the need of clearing the surroundings of homesteads to create unfavourable conditions for both host and vector. While reduction of fallow cycles to minimize both host and vector populations would seem appropriate under such circumstances, there is need for a compromise between plague risk avoidance and environmental conservation in terms of erosion control.

\section{Acknowledgements}

This work was supported by the Sokoine University of Agriculture - Flemish Interuniversity Council (SUA-VLIR) Own Initiative Project - 'Landscape-Ecological Clarification of Bubonic Plague Distribution and Outbreaks in the Western Usambara Mountains, Tanzania' (Acronym: LEPUS), funded by the Flemish Interuniversity Council, Belgium. The authors gratefully acknowledge the contribution of Dr. Anne Laudisoit (Department of Biology, University of Antwerp, Belgium) for the identification of flea species. The authors also greatly appreciate the cooperation of many people including farmers in the study area, staff of Lushoto District Council and Sebastian Kolowa Memorial University.

\section{References}

Aertsen, W., Kint, V., De Vos, B., Deckers, J., Van Orshoven, J. \& Muys, B. (2012) Predicting forest site productivity in temperate lowland from forest flor, soil and litterfall characteristics using boosted regression trees. Plant Soil 354, 157-172.

Arinaminpathy, N., McLean, H.N. \& Godfray, H.C.J. (2009) Future UK land use policy and the risk of infectious disease in humans, livestock and wild animals. Land Use Policy 26S, S124-S133.

Axelsson, E.P., Hjältén, J., LeRoy, C.J., Thomas, G., Whitham, T.G., Julkunen-Tiitto, R. \& Wennström, A. (2011) Leaf litter from insect-resistant transgenic trees causes changes in aquatic insect community composition. Journal of Applied Ecology 48, 1472-1479.

Ben Ari, B.T., Neerinckx, S., Gage, K.L., Kreppel, K., Laudsoit, A., Leirs, H \& Stenseth, N. (2011) Plague and Climate: Scale Matter. PLoS Pathogy 7(9), e1002160. 
Davis, S., Makundi, R.H., Machang'u R.S. \& Leirs, H. (2006) Demographic and spatio-temporal variation in human plague at a persistent focus in Tanzania. Acta Tropica 100, 133-141.

Debien, A., Neerinckx, S., Kimaro, D. \& Gulinck, H. (2010) Influence of satellite-derived rainfall patterns on plague occurrence in northeast Tanzania. International Journal of Health Geographics 9, 60.

Eisen, R.J., Borchert, J.N., Mpanga, J.T., Atiku, L.A., MacMillan, K., Boegler, K.A., Montenieri, J.A., Monaghan, A. \& Gage, K.L. (2012) Flea diversity as an Element for Persistence of Plague Bacteria in an East African Plague Focus. PLoS One 7(4): e35598.

Eisen, R.J., Bearden, S.W., Wilder, A.P, Montenieri, J.A., Antolin, M.F. \& Gage, K.L. (2006) Early phase transmission of Yersiania pestis by unblocked fleas as a mechanism explaining rapidly spreading plague epizootics. Proceedings of the National Academy of Science of the United States 103, 15380-15385.

Eisen, R.J., Griffith, K.S., Borchert, J.N., McMillan, K., Apangu, T., Owor, N., Acayo, S., Acidri, R., Zielinski-Gutierrez, E., Winters, A.M., Enscore, R.E., Schriefer, M.E., Beard, C.B., Gage, K.L. \& Mead, P.S. (2010) Assessing Human Risk of Exposure to Bacteria in North-western Uganda Based on Remotely Sensed Predictors. American Journal of Tropical Medicine and Hygiene 82, 904-911.

Elith, J., Leathwick, J.R. \& Hastie, T. (2008) A working guide to boosted regression trees. Animal Ecology 77, 802-813.

Gage, K.L., Burkot, T.R., Eisen, R.J. \& Hayes, E.B. (2008) Climate and vector-borne diseases. American Journal of Preventive Medicine 35, 436-450.

Haeselbarth, E., Segerman, J. \& Zumpt, F. (1966) The arthropod parasites of vertebrates in Africa (Ethiopian region). Publications of the South African Institute for Medical Research 13, 117-250.

Hubbart, J.A., Jachowski, D.S. \& Eads, D.A. (2011) Seasonal and among-site variation in the occurrence and abundance of fleas on California ground squirrels (Otospermophilus beecheyi). Journal of Vector Ecology 36, 117-123.

Hubeau, M. (2010) Land use and human activity patterns in relation to the plague disease in the West Usambara Mountains, Tanzania. MSc. Dissertation, K.U.Leuven, Belgium. 102pp.

Kamugisha, M.L., Gesase, S., Minja, D., Mgema, S., Mlwilo, T.D., Mayala, B.K., Msigwa, S., Massaga, J.J., \& Lemnge, M.M. (2007) Pattern and spatial distribution of plague in Lushoto, north-eastern Tanzania. Tanzania Health Research Bulletin 9, 12-18.

Kaoneka, A.R.S. \& Solberg, B. (1994) Forestry related land use in West Usambara mountains, Tanzania. Agriculture, Ecosystems and Environment 49, 207-215.

Kaoneka, A.R.S. \& Solberg, B. (1997) Analysis of deforestation and economically sustainable farming systems under pressure of population growth and income constraints at the village level in Tanzania. Agriculture, Ecosystem and Environment 62, 59-70.

Kilonzo, B.S., Mvena, Z.S.K., Machangu, R.S. \& Mbise, T.J. (1997) Preliminary observations on factors responsible for long persistence and continued outbreaks of plague in Lushoto District, Tanzania. Acta Tropica 68, 215-227.

Laudisoit, A. (2009) Diversity, Ecology and Status of Potential Hosts and Vectors of the Plague Bacillus Yersinia pestis. Contribution to the Plague Epidemiology in an Endemic Plague Focus: The Lushoto District, Tanzania. PhD Thesis, Universiteit Antwerpen, Belgium. 259pp.

Laudisoit, A., Leirs, H., Makundi, R.H. \& Krasnov, B. (2009a) Seasonal and habitat dependence of fleas parasitic on small mammals in Tanzania. Integrative Zoology 4, 196-212.

Laudisoit, A., Leirs, H., Makundi, R.H., Van Dongen, S., Davis, S., Neerinckx, S., Deckers, J. \& Libois, R. (2007) Plague and the human flea, Tanzania. Emerging Infectious Diseases 13, 687-693.

Laudisoit, A., Neerinckx, S., Makundi, R.H., Leirs, H. \& Krasnov, B. (2009b) Are local plague endemicity and ecological characteristics of vectors and reservoirs related? A case study in north-east Tanzania. Current Zoology 55, 199-211. 
Linard, C., Lamarque, P., Heyman, P., Ducofftre, G., Luyasu, V., Tersago, K., Vanwambeke, O.S. \& Lambin, E.F. (2007) Determinants of the geographic distribution of Puumala virus and Lyme borreliosis infection in Belgium. International Journal of Health Geographics 6, 15.

Makundi, R.H., Massawe, A. \& Mulungu, L. (2005) Rodent population fluctuations in three ecologically heterogeneous locations in northeast, central and south west Tanzania. Belgian Journal of Zoology 135, 159-165.

Makundi, R.H., Massawe, A.P., Mulungu, L.S., Katakweba, A., Mbise, T.J. \& Mgode, G. (2008) Potential mammalian reservoirs in a bubonic plague outbreak focus in Mbulu District, northern Tanzania, in 2007. Mammalia 72, 253-257.

Massawe, A., Rwamgira, W., Leirs, H., Makundi, R.H. \& Mulungu, L.(2006) Do farming practices influence population dynamics of rodents? A case study of the multimammate field rats, Mastomys natalensins, in Tanzania. African Journal of Ecology 45, 293-301.

MacMillan, K., Enscore, R.E., Ogen-Odoi, A., Borchert, J.N., Babi, N., Amatre, G., Atiku, L.A., Mead, P.S., Gage, K.L. \& Eisen, R.J. (2011) Landscape and Residential Variables Associated with Plague-Endemic Villages in the West Nile Region of Uganda. American Journal of Tropical Medicine and Hygiene 84, 435-442.

Msita, H.B., Kimaro, D.N., Deckers, J. \& Poesen, J. (2010) Identification and Assessment of Indigenous Soil Erosion Control Measures in the Usambara Mountains, Tanzania. Chapter 3 in Earl T. Nardal (Editor). No-Till Farming: Effects of Soil, Pros and Cons and Potential. Agriculture Issues and Policies Series. ISBN: 978-1-60741-402-5. Nova Science Publishers Inc, New York: 49-74.

Msita, H.B., Kimaro, D.N., Kihupi, N.I., Dondyene, S., Msanya, B. M., Mtakwa, P.W., Poesen, J. \& Deckers, J. (2011) Evolution of Miraba: An Indigenous Soil Erosion Control Technology in the Western Usambara Mountains, Tanzania. Paper presented to the International congress on: Integrated water-resources management in tropical and subtropical dry lands held at Mekelle, Ethiopia from 19-26 September 2011.

Mulungu, L.S., Mahlaba, T.A., Massawe, A.W., Kennis, J., Crauwels, D., Eiseb, S., Monadjem, A., Makundi, R.H., Katakweba, A.A.S., Leirs, H. \& Belmain, S,R. (2011) Dietary differences of the multimammate mouse, Mastomys natalensins (Smith, 1834), across different habitats and seasons in Tanzania and Swaziland. Wildlife Research 38, 640-646.

Neerinkx, S., Peterson, A.T., Gulinck, H., Deckers, J., Kimaro, D. \& Leirs, H. (2010) Predicting potential risk areas of human plague for the Western Usambara Mountains, Lushoto District Tanzania. American Journal of Tropical Medicine and Hygiene 82, 492-500.

Nienhuis, C.M. \& Stout, J.C. (2009) Effectiveness of native bumblebees as pollinators of the alien invasive plant impatiens Glandulifera (Balsaminaceae) in Ireland. Journal of Pollination Ecology 1, 1-11.

Njunwa, K.J., Mwaiko, G.L., Kilonzo, B.S. \& Mhina, J.I. (1989) Seasonal patterns of rodents, fleas and plague status in the Western Usambara Mountains, Tanzania. Medical and Veterinary Entomology 3, 17-22.

Patz, J.A., Daszak, P., Tabor, G.M., Aguirre, A., Pearl, M., Epstein, J., Wolfe, N.D., Kilpatrick, A.M., Foufopoulos, J., Molyneux, D., Bradley, D.J. \& Members of Working Group on Land Use Change and Disease Emergence (2004) Unhealthy Landscapes: Policy Recommendations on Land Use Change and Infectious Disease Emergence. Environmental Health Perspectives 112, $1092-1098$.

Pfeiffer, R. (1990) Investigating possibilities of combining fodder production with erosion control and agroforestry in the West Usambara Mountains of Tanzania: In J. Kotchi (Ed) Ecofarming Practices for Tropical Smallholdings. 185p. Margraf, Series. ISBN 3823611844.

Pham, H.V., Dang, D.T., Minh, N.T., Nguyen, N.D. \& Nguyen, T.V. (2009) Correlates of environmental factors and human plague: an ecological study in Vietnam. International Journal of Epidemiology 38, 1634-1641. 
R Development Core Team. (2006) R: A Language and Environment for Statistical Computing. R Foundation for Statistical Computing, Vienna. [www.ipensieri] Site visited on 06.09.2011.

SAS Resource on the web. (2012) On biostatistics and clinical trials. [http://onbiostatistics.blogspot.com/2012_05_01_archive.html]. Accessed on 26.03.2014.

Sokolow, S.H., Foley, P., Foley, J.E., Hastings, A. \& Richardson, L.L. (2009) Disease dynamics in marine metapopulations: modelling infectious diseases on coral reefs. Journal of Applied Ecology 46, 621-631.

Vanwambeke, S.O., Bennett, S.N. \& Kapan, D.D. (2011) Spatially disaggregated disease transmission risk: land cover, land use and risk of dengue transmission on the Island of Oahu. Tropical Medicine and International Health 16, 174-185.

Williams, G.J., Aeby G.S., Cowie, R.O.M. \& Davy, S.K. (2010) Predictive Modelling of Coral Disease Distribution within a Reef System. PLoS One 5(2), e9264.

Zimba, M., Pfukenyi, D., Loveridge, J. \& Mukaratirwa, S. (2011) Seasonal abundance of plague vector Xenopsylla brasiliensis from rodents captured in three habitat types of periurban suburbs of Harare, Zimbabwe. Vector-Borne and Zoonotic Diseases 11, 1187-1192.

Zuur, A.F, leno, E.N. \& Elphic, C.S. (2010) A protocol for data exploration to avoid common statistical problems. Methods in Ecology and Evolution 1, 3-14. 